\section{Screening of Sex in Asparagus at Early Growth Stages}

\author{
Yusuke Ii, Yuichi Uno ${ }^{1}$, Michio Kanechi, and Noboru Inagaki
}

AdDitIONAL INDEX WORDs. Asparagus officinalis, molecular marker, multiplex PCR, raising seedlings, sex determination

SUMMARY. To determine the sex of asparagus (Asparagus officinalis) at the seedling stage, an easy, economical, and reliable method was developed. We used a modified single-step DNA extraction protocol, which resulted in a crude extract containing sufficient genomic DNA for use as a template. The male-specific marker (AsplT7sp) is a dominant marker and may lead to false negatives caused by an incomplete reaction; therefore, a multiplex polymerase chain reaction (PCR) was developed using a ribosomal RNA gene marker. The resulting banding pattern distinguished males from females without false negatives. To determine the best tissue for extraction of template DNA, phylloclades (a specialized stem that resembles and functions like a leaf) or root tips of individual asparagus plants were collected and weighed. A $4.0-\mathrm{mg}$ phylloclade sample or a $0.8-\mathrm{mg}$ root sample provided sufficient DNA for PCR analysis of asparagus. Root excision at day 19 did not affect subsequent growth of asparagus seedlings after 28 days. The method can determine the sex of asparagus at day 19 after seeding. A combination of single-step DNA extraction from root tips and multiplex PCR made for a simple and reliable screening method.

A sparagus is an economically important perennial, dioecious vegetable crop. Male asparagus plants usually produce greater spear yields than females (Ellison, 1986; Moon, 1976; Sinton and Wilson, 1999). Male plants do not create the weed problem that results from asparagus seedlings from female plants (Ellison, 1986). The volunteer asparagus seedlings reduce the $\mathrm{F}_{1}$ genetic purity of a production field, often resulting in long-term reductions in quality and vigor (Walker et al., 1999). On the other hand, female plants produce thicker spears (Uesugi et al., 1992; Uragami, 1988). However, the geographic isolation of males and females can produce the desired quality of spears and prevent seed production. Seedlings must, however, be grown for 1-2 years after transplantation until flowering to distinguish male from female plants (Sneep, 1953). The sexdetermining locus in asparagus is referred to as $\mathrm{M}$ (the male-determining gene) and $\mathrm{m}$ (the female-determining gene). Females are homogametic ( $\mathrm{mm})$, and males are heterogametic $(\mathrm{Mm})$. Supermales (MM) are desirable for the production of all-male asparagus progeny and to ensure that female plants

Department of Plant Resource Science, Graduate School of Agricultural Science, Kobe University, Rokko, Kobe 657-8501, Japan

${ }^{1}$ Corresponding author. E-mail: yuno@kobe-u.ac.jp. are not transplanted into the field. Self-pollination of andromonoecious plants (Sneep, 1953) or doubled haploid lines produced by anther and/or microspore culture (Falavigna, 1979; Falavigna et al., 1990, 1996; Inagaki et al., 1980; Shiga et al., 2009; Torrey and Peirce, 1983) have made it possible to breed supermale asparagus plants. Thus, the practical application of an all-male hybrid cultivar has progressed from possibility to actuality, for example the cultivars Gijnlim (bred in The Netherlands) and Zuiyu (Uragami et al., 2011). The limited number of all-male cultivars remains a problem because those available lack adaptations to a cropping type for white or green asparagus, have reduced quality, lack resistance to local pathogens, and lack the ability to adapt to a variety of climates. Indeed, a mix of male and female plants is still planted in most of the asparagus fields.

The development of molecular markers linked to sex-determining chromosome segments would enable the simplification and promotion of the breeding of supermale individuals and the cultivation of males only. Many attempts to identify genetic markers linked to sex determination in asparagus have been undertaken. Such studies have used isoenzyme markers (Maestri et al., 1991); restriction fragment length polymorphism markers (Biffi et al., 1995); randomly amplified polymorphic DNA (RAPD) markers (Gebler et al., 2007); RAPD and sequence-characterized amplified region (SCAR) markers (Jiang and Sink, 1997); and amplified fragment length polymorphism, SCAR markers, or both (Jamsari et al., 2004; Nakayama et al., 2006; ReamonBüttner et al., 1998; Reamon-Büttner and Jung, 2000). The male-specific marker (Aspl-T7) was first detected as being closely linked to the sexdetermining locus by Jamsari et al. (2004). It was developed as a common marker, Aspl-T7sp, in many types of cultivars by Nakayama et al. (2006). Furthermore, this marker was applied to a loop-mediated isothermal amplification method (Shiobara et al., 2011). However, the practical use of primers for Asp 1-T7sp is sometimes reduced by the presence of false negatives, where a male plant is wrongly scored as female. This misrecognition is mainly the result of an incomplete PCR reaction, caused by the quality and/or quantity of DNA template, and/or contamination by inhibitors. To overcome this, a multiplex PCR reaction would be a useful way to amplify the target fragment together with a reaction control. Multiplex PCR has been developed for the detection of different pathogens (Fraaije et al., 2001; Pastrik, 2000; Winton and Hansen, 2001). Multiplex PCR was used to determine the sex of papaya (Carica papaya) plants (Parasnis et al., 2000; Urasaki et al., 2002). We also tried to develop an improved, rapid, and easy method of DNA extraction

\begin{tabular}{llll}
\hline $\begin{array}{l}\text { Units } \\
\begin{array}{l}\text { To convert U.S. to SI, } \\
\text { multiply by }\end{array}\end{array}$ & U.S. unit & SI unit & $\begin{array}{l}\text { To convert SI to U.S., } \\
\text { multiply by }\end{array}$ \\
\hline 29,574 & $\mathrm{fl} \mathrm{oz}$ & $\mu \mathrm{L}$ & $3.3814 \times 10^{-5}$ \\
29.5735 & $\mathrm{fl} \mathrm{oz}$ & $\mathrm{mL}$ & 0.0338 \\
2.54 & inch $(\mathrm{es})$ & $\mathrm{cm}$ & 0.3937 \\
25.4 & inch $(\mathrm{es})$ & $\mathrm{mm}$ & 0.0394 \\
28.3495 & $\mathrm{oz}$ & $\mathrm{g}$ & 0.0353 \\
28,350 & $\mathrm{oz}$ & $\mathrm{mg}$ & $3.5274 \times 10^{-5}$ \\
$\left({ }^{\circ} \mathrm{F}-32\right) \div 1.8$ & ${ }^{\circ} \mathrm{F}$ & ${ }^{\circ} \mathrm{C}$ & $\left(1.8 \times{ }^{\circ} \mathrm{C}\right)+32$
\end{tabular}


from asparagus. In almost all studies of asparagus sex markers, a cetyltrimethyl ammonium bromide (CTAB) method, with or without modification (Gebler et al., 2007; Jiang and Sink, 1997; Nakayama et al., 2006; ReamonBüttner et al., 1998), or a commercial kit based on benzyl chloride method (Shiobara et al., 2011) has been used for DNA preparation. These methods are time-consuming and involve high costs for some reagents and kits. This problem could be solved using a smallscale crude extraction because PCR screening does not require purified DNA. Thomson and Henry (1995) reported single-step plant DNA extraction for PCR. We applied this method to save cost and time. Previously, samples for DNA extraction have been limited to phylloclades or stalks in asparagus because aboveground parts could be collected easily from potted or field-grown plants. We examined the use of roots for crude DNA samples to hasten the date for sex determination before the production of seedlings.

In this study, a practical screening of sex in asparagus at early growth stages was established by the application of simple DNA extraction and multiplex PCR from root tips of young seedlings.

\section{Materials and methods}

Plant material. Asparagus cultivars Mary Washington 500W (MW500W; Takii \& Co., Kyoto, Japan), Shower (Takii \& Co.), Baitoru (Kaneko Seeds Co., Maebashi, Japan), and Poletom (Sakata Seed Corp., Yokohama, Japan) were used in this study. The cultivar Gijnlim (Pioneer Ecoscience Co., Tokyo, Japan) was selected as a representative all-male line. All plant populations were grown in an experimental field, a glass greenhouse, or a thermostatic chamber room of Kobe University, Kobe, Japan. For root excision, seeds were sown in plastic petri dishes with three filter papers, moistened with $6 \mathrm{~mL}$ of distilled water. The root tips were cut into 5- or 10-mm-long segments for genomic DNA extraction. Phylloclades were gathered from field-grown plants.

Single-ster DNA EXtraction. Phylloclades or root tips of individual asparagus seedlings were collected in 1.5-mL microtubes. DNA was extracted according to Thomson and
Henry (1995), with some modification as follows. After adding $100 \mu \mathrm{L}$ of extraction buffer [ $100 \mathrm{~mm}$ tris (hydroxymethyl)aminomethane-hydrogen chloride, $1 \mathrm{~mol} \cdot \mathrm{L}^{-1}$ potassium chloride, $10 \mathrm{mmol} \cdot \mathrm{L}^{-1}$ ethylenediaminetetraacetic acid (EDTA), pH 9.5], each sample was homogenized with a plastic pestle, mixed vigorously by a microtube mixer for $30 \mathrm{~s}$, and incubated at $95{ }^{\circ} \mathrm{C}$ for $10 \mathrm{~min}$. The heated samples were mixed vigorously again by a microtube mixer for $30 \mathrm{~s}$, and the supernatant was used as the PCR template after a brief centrifugation.

Multiplex PCR analysis. Two sets of primer pairs were used for the multiplex PCR. To amplify an asparagus male-specific fragment, the Asp 1T7sp primer set (Nakayama et al., 2006 ) was used: forward primer $\left(5^{\prime}\right.$ ATATGCGAGGCATTTGGAAG- ${ }^{\prime}$ ) and reverse primer $\left(5^{\prime}\right.$-CTGCTACT GAGATACCTTAC- $3^{\prime}$ ). The other primer pair, forward primer $\left(5^{\prime}\right.$ CCTGCCTCGCTGCAGAA-3' ) and reverse primer $\left(5^{\prime}\right.$-GCATTGGCT TAGGGTCGAG-3' ), amplified a universal asparagus fragment as a reaction control. Both primers were designed from the partial sequence of the ribosomal RNA gene (accession no. HM990105). The 30- $\mu$ Lreaction mixture for duplex PCR was prepared as follows: $1 \times$ Ampdirect buffer (Shimazu, Kyoto, Japan), $0.73 \mu \mathrm{mol} \cdot \mathrm{L}^{-1}$ of each primer, 0.6 units of BIOTAQ HS (Shimazu), and $1 \mu \mathrm{L}$ of crude DNA template. The PCR was carried out with a GeneAmp PCR System 9700 (PerkinElmer, Waltham, MA) thermocycler. The following PCR conditions were used: denaturation for $10 \mathrm{~min}$ at $95^{\circ} \mathrm{C}$; followed by $45 \mathrm{cy}$ cles of $94^{\circ} \mathrm{C}$ for $50 \mathrm{~s}, 60^{\circ} \mathrm{C}$ for $50 \mathrm{~s}$, and $72^{\circ} \mathrm{C}$ for $50 \mathrm{~s}$; and a final elongation at $72{ }^{\circ} \mathrm{C}$ for $10 \mathrm{~min}$. Amplified products were electrophoresed alongside molecular weight markers on a $1.5 \%$ agarose gel in $1 \times$ Tris/borate/ EDTA buffer and stained with ethidium bromide. Gels were observed and photographed under ultraviolet light. The observed values for segregation of sex in three cultivars were analyzed by a $\chi^{2}$ test, with an expected ratio of $1: 1$.

Growth MEASUREMENT OF YOUNG SEEDLINGS. Forty seeds of 'MW500W' were sown in a plastic petri dish with three filter papers, moistened with $6 \mathrm{~mL}$ of $160 \mathrm{ppm}$ captan solution, and incubated at
$23{ }^{\circ} \mathrm{C}$. After $19 \mathrm{~d}, 10$ seedlings were selected at random for each plot (three replicates). A total of 30 seedlings were used for each treatment. The root tips of seedlings were excised at length 0 (control), 5, and $10 \mathrm{~mm}$ and weighed. Root-excised seedlings were grown in 100-mL pots filled with white exfoliated vermiculite at $23{ }^{\circ} \mathrm{C}$ in a thermostatic chamber. After $28 \mathrm{~d}$, the following parameters were measured to evaluate the influence of root excision: the survival ratio, the number of shoots, and the length and weight (fresh and dry) of the longest shoot. To measure dry weight, a fresh sample was dried at 80 to $85^{\circ} \mathrm{C}$ for over $48 \mathrm{~h}$ in a forced air drier. The parameters, except the survival ratio, were analyzed statistically using the Tukey-Kramer honestly significant difference test. The survival ratio was analyzed nonparametrically by a Kruskal-Wallis multiple comparison test.

\section{Results}

Multiplex PCR using CRUde DNA SOLUTION FROM PHYLLOCLADES. As a first step to examine the conditions for multiplex PCR, an independent reaction was carried out for each marker using genomic DNA from 15.5-mg phylloclade of field-grown all-male 'Gijnlim' asparagus as a positive control. Figure $1 \mathrm{~A}$ indicates that PCR fragments for both Aspl-T7sp [308 base pair (bp)] and ribosomal RNA gene (493 bp) were amplified as single bands, with no nonspecific minor bands. The markers were then coamplified in the same PCR tube. Figure $1 \mathrm{~B}$ shows the multiplex PCR with DNA samples extracted from various weights of phylloclades in 'Gijnlim' asparagus. Of the 20 phylloclade samples, ranging in weight from 1.3 to $19.6 \mathrm{mg}$ (fresh weight), 16 samples of more than $4.0 \mathrm{mg}$ clearly generated both fragments. Two samples under $1.9 \mathrm{mg}$ generated a smeared band pattern. The other two samples, comprising genomic DNA extracted from 2.5 and $2.9 \mathrm{mg}$ of phylloclades, respectively, showed an unclear band for the ribosomal RNA gene and a somewhat clearer band for the Aspl-T7sp marker. In this case, we designated the results as "not determined": not female, but an incomplete reaction. This classification will increase the proportion of correctly identified male plants. As expected, the shorter fragment 
A

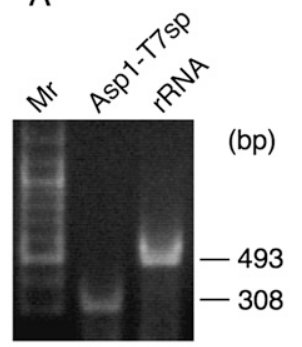

B
C

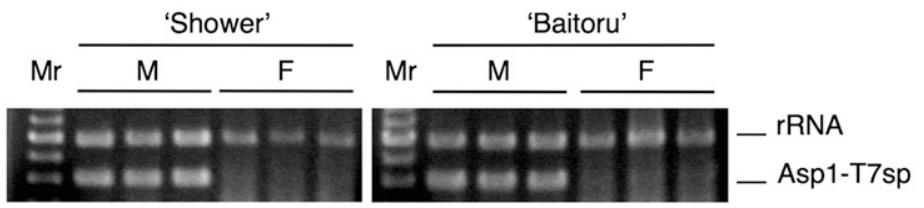

Weight of phylloclades (mg)

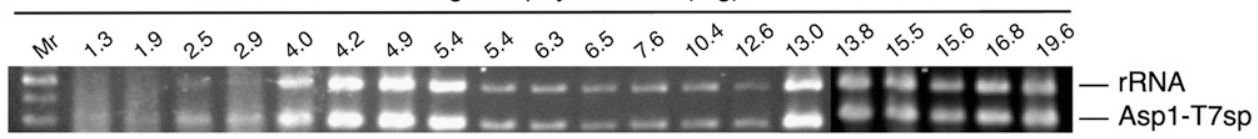

Fig. 1. Fragments amplified by polymerase chain reaction (PCR) using male-specific primers (Aspl-T7sp) and control primers [ribosomal RNA (rRNA)] with genomic DNA templates extracted from phylloclades (a specialized stem that resembles and functions like a leaf) of asparagus. Each cultivar was grown in an experimental field for 1 year ('Gijnlim') or 2 years ('Shower' and 'Baitoru'). (A) Each fragment was amplified to verify the size and the specificity with all-male cultivar Gijnlim. The leftmost lane represents a molecular marker (Mr). (B) Multiplex PCR using mixed primer sets was carried out with genomic DNA extracted from 20 phylloclade samples of 'Gijnlim', ranging in fresh weight from 1.3 to $19.6 \mathrm{mg}$. The male banding pattern was detected only from phylloclade samples weighing more than $4.0 \mathrm{mg}$. (C) Sex of asparagus was determined by multiplex PCR with male $(\mathrm{M})$ or female $(\mathrm{F})$ of normal cultivars Shower and Baitoru; $1 \mathrm{mg}=3.5274 \times 10^{-5} \mathrm{oz}$.

[Aspl-T7sp (308 bp)] was more easily amplified than the longer one [ribosomal RNA gene (493 bp)]. This indicates that the long fragment is a good reaction control marker for PCR. Figure 1C shows the sex determination with normal cultivars Shower and Baitoru, using more than $4.0 \mathrm{mg}$ of phylloclades. Multiplex PCR analysis revealed that no malespecific Aspl-T7sp fragments were amplified from female individuals and that endogenous ribosomal RNA fragments were observed in all samples. This result indicates that the multiplex PCR used in this study is consistent between the two cultivars tested.

Growth MEASUREMENT OF SEEDLINGS AFTER ROOT EXCISION. TO determine whether roots are suitable for generating DNA samples, the influence of excision on the growth of the seedlings was evaluated. Table 1 shows a comparison of the growth of asparagus 'MW500W' seedlings with or without root excision. Both the fresh weight of the excised root and the ratio to total fresh weight were significantly different between 5 and $10 \mathrm{~mm}(P<0.05)$. These results indicate that the weight of root is proportional to the length of the excised part. Surprisingly, growth was not decreased by the damage caused by excision. At day 28 from planting, all the growth parameters, including survival rate, the number of shoots, length, and fresh and dry weight of the longest shoot were similar among the three treatments: 0 - (control), 5-, and $10-\mathrm{mm}$ root excisions (Table $\mathrm{l}$ ). There was no strong correlation (correlation coefficient $<0.7$ ) detected between the fresh weight ratio of the excised root to total plant and dry matter percentage after $28 \mathrm{~d}$ (Fig. $2 \mathrm{~A}$ and $\mathrm{B})$. These results suggest that 5 - to 10-mm root excision does not affect the growth of the asparagus seedlings, and the excised parts could be used for genomic DNA extraction.

Multiplex PCR USING DNA FrOM ROOTs. Template genomic DNA was extracted from roots of 'Gijnlim' asparagus seedlings sown in petri dishes. The roots were excised in 5 - or $10-\mathrm{mm}$ length, resulting in 31 different weights ranging from 0.8 to $107 \mathrm{mg}$. Figure 3 shows the results of multiplex PCR. Both the male-specific and endogenous PCR products were observed in all samples. Root samples from a normal asparagus cultivar were also tested, and males and females could be determined by their banding patterns (Table 2). Although the validity of the method could only be determined when the seedlings grew, all probability values for the $\chi^{2}$ test were more than 0.05 (i.e., it could not contradict the expected $1: 1$ ratio). Success rates of sex determination were $100 \%$ ('Shower' and 'Poletom') and 96\% ('Baitoru'), respectively.
Thus, the sex determination method based on multiplex PCR is applicable to excised roots of asparagus seedlings.

\section{Discussion}

In this study, we showed that a single-step DNA extraction and multiplex PCR method was less costly and prevented false negatives. For example, a commercial kit, which uses the standard CTAB method, would be $\approx 6000$ times more expensive than the single-step DNA extraction method. It also consumes four times as much labor over the duration of the extraction. DNA markers based on PCR for identification of asparagus sex have been reported (Gebler et al., 2007; Jamsari et al., 2004; Jiang and Sink, 1997; Nakayama et al., 2006; Reamon-Büttner et al., 1998; Reamon-Büttner and Jung, 2000). In some reports, $1-5 \mathrm{~g}$ of phylloclade was used for extracting genomic DNA. It is difficult to prepare such an amount from young asparagus seedlings at $47 \mathrm{~d}$ after seeding, whose longest shoots ranged from 51.9 to $70.1 \mathrm{mg}$. We succeeded in minimizing the scale of DNA preparation to $4.0 \mathrm{mg}$ of phylloclades (Fig. 1B) and $0.8 \mathrm{mg}$ of roots (Fig. 3). Compared with the PCRamplified bands from crude DNA of roots, those from phylloclades were not uniform, even using the same amount of sample [Fig. 1B; lane 9 
Table 1. Effect of excision of roots on seedling growth in asparagus. The root tips of 19-d-old seedlings were excised at length 0 (control), 5 , and $10 \mathrm{~mm}$. The growth of root-excised seedlings was characterized at day 28 . Root to whole seedling ratio was calculated based on fresh weight.

\begin{tabular}{|c|c|c|c|c|c|c|c|}
\hline \multicolumn{3}{|c|}{ Feature of excised root } & \multicolumn{5}{|c|}{ Growth characteristics of seedling } \\
\hline $\begin{array}{l}\text { Length } \\
(\mathrm{mm})^{\mathrm{z}}\end{array}$ & $\begin{array}{c}\text { Fresh wt } \\
{[\text { mean } \pm \text { SE }} \\
(\mathrm{mg})]^{\mathrm{z}}\end{array}$ & $\begin{array}{c}\text { Root to whole } \\
\text { seedling ratio } \\
{[\text { mean } \pm \text { SE }(\%)]^{\mathrm{y}}}\end{array}$ & $\begin{array}{c}\text { Survival } \\
\text { rate }^{\mathrm{x}}\end{array}$ & $\begin{array}{c}\text { Shoots } \\
{[\text { mean } \pm \text { SE }} \\
(\text { no. })]\end{array}$ & $\begin{array}{c}\text { Shoot length } \\
{[\text { mean } \pm \text { SE }} \\
(\mathrm{cm})]^{\mathrm{w}}\end{array}$ & $\begin{array}{c}\text { Shoot fresh wt } \\
{[\text { mean } \pm S E} \\
(\mathrm{mg})]^{\mathrm{w}}\end{array}$ & $\begin{array}{c}\text { Shoot dry } \\
\text { matter } \\
{[\text { mean } \pm \text { SE }(\%)]^{v}}\end{array}$ \\
\hline 5 & $2.0 \pm 0.2 \mathrm{a}^{\mathrm{u}}$ & $3.2 \pm 0.2 \mathrm{a}^{\mathrm{u}}$ & $96.7 \mathrm{a}$ & $1.4 \pm 0.1 \mathrm{a}$ & $13.7 \pm 1.4 \mathrm{a}$ & $51.9 \pm 6.2 \mathrm{a}$ & $18.3 \pm 0.9 \mathrm{a}$ \\
\hline 10 & $3.6 \pm 0.3 b$ & $6.1 \pm 0.5 b$ & $90.0 \mathrm{a}$ & $1.3 \pm 0.1 \mathrm{a}$ & $16.4 \pm 0.9 \mathrm{a}$ & $63.7 \pm 4.1 \mathrm{a}$ & $20.4 \pm 0.8 \mathrm{a}$ \\
\hline
\end{tabular}

${ }^{\mathrm{z}} \mathrm{l} \mathrm{mm}=0.0394$ inch, $\mathrm{l} \mathrm{mg}=3.5274 \times 10^{-5} \mathrm{oz}$.

$\mathrm{y}($ Fresh weight of excised root/fresh weight of whole seedling $) \times 100$.

xPercentage data of survival rate were analyzed nonparametrically by Kruskal-Wallis multiple comparison test. Different letters indicate significant differences at $P=0.05(r=3)$. "Shoot length, fresh weight, and dry weight were measured for the longest shoot; $1 \mathrm{~cm}=0.3937$ inch.

$\mathrm{v}($ Dry weight of the longest shoot/fresh weight of the longest shoot $) \times 100$.

"Data, except survival rate, shown are mean values \pm SE for $r=3$ and $n=10$. Different letters indicate significant differences at $P=0.05$ by the Tukey-Kramer honestly significant difference test.
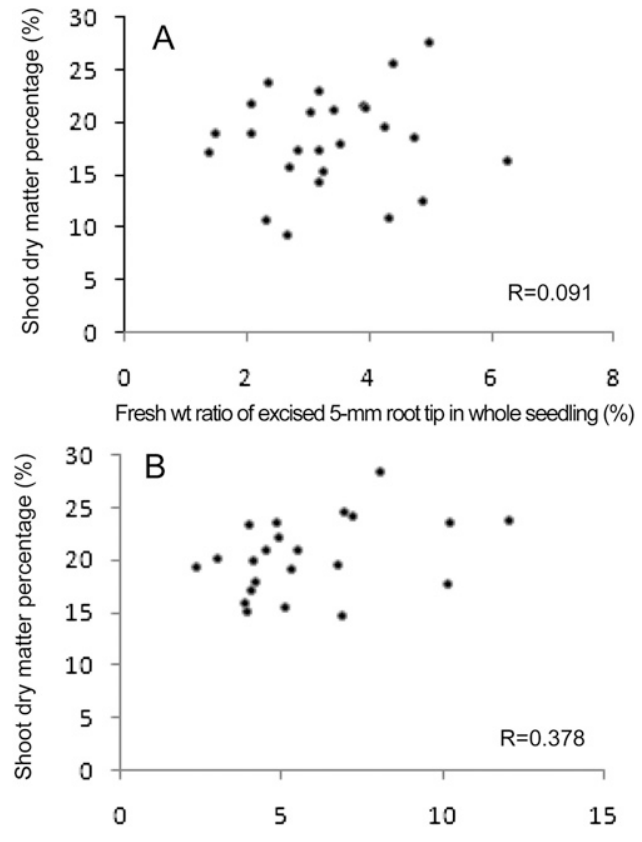

Fresh wt ratio of excised 10-mm root tip in whole seedling (\%)

Fig. 2. Correlation of the fresh weight ratio of excised (A) $5-\mathrm{mm}$ or (B) $10-\mathrm{mm}$ root tips in whole seedlings with dry matter percentage in asparagus. Ratio to total fresh weight was calculated with the following formula: (fresh weight of excised root/ fresh weight of whole seedling) $\times 100$. In seedlings with cut roots after $28 \mathrm{~d}$ from planting, dry matter percentage was calculated with the following formula: (dry weight of the longest shoot/fresh weight of the longest shoot $) \times 100 . R$ represents the correlation coefficient; $1 \mathrm{~mm}=0.0394$ inch.

and 10 (5.4 $\mathrm{mg}$ in weight)]. This might be caused by nonuniformity in the extraction, PCR amplification, or both. The PCR could be affected by the difference in yield balance between the amount of DNA and inhibitors after extraction; the phylloclade is a developed, firm tissue. Another reason for the nonuniformity of crude samples of phylloclades might be their high DNA concentration. An approximate spectrophotometric estimation of crude samples from phylloclades demonstrated 6-8 times higher values of A260 (i.e., DNA and RNA), A230 (i.e., polysaccharides), and A280 (i.e., proteins) than those from roots or shoots of young seedlings (data not shown). This is the first report of successful sex determination using DNA extracted from root tip samples. Only 5-10 $\mathrm{mm}$ of excised roots is required for extracting sufficient DNA template (Fig. 3), and this method saves time because it avoids a precise weighing step. Moreover, space and materials for raising seedlings can be dispensed with, because sex of asparagus can be screened in the laboratory. The marker was successfully PCR amplified from genomic DNA extracted from shoots of young seedlings, as well as from roots (data not shown). Although the shoots can also provide sufficient DNA for PCR analysis, there was a delay of $8 \mathrm{~d}$ to allow collection of shoots of $5-10 \mathrm{~mm}$ in length compared with roots. A single-step DNA extraction protocol (Thomson and Henry, 1995) was applied to asparagus in this study, and the crude DNA extract was sufficient for PCR. Although the single-step DNA extraction might decrease the purity of DNA as compared with other methods, such as CTAB, it has advantages in cost, simplicity, and speed. The DNA templates were relatively stable; repeated amplification was successful from 15 samples stored at $-20{ }^{\circ} \mathrm{C}$ for $7,14,30$, and $150 \mathrm{~d}$ after extraction (data not shown).

We optimized the annealing temperature and primer concentration precisely for multiplex PCR (data not shown), as did in previous studies (Parasnis et al., 2000; Pastrik, 2000). The male-specific marker, Aspl-T7sp, (Nakayama et al., 2006) is a dominant DNA marker and can lead to false negatives. To prevent false negatives, an internal control fragment was amplified as a reaction marker in other species (Parasnis et al., 2000; Pastrik, 2000; Urasaki et al., 2002; Winton and Hansen, 2001). Although these control markers were designed as smaller fragments than the target marker fragment, our designed ribosomal RNA fragment was larger than the Asp 1-T7sp fragment. Thus, under 


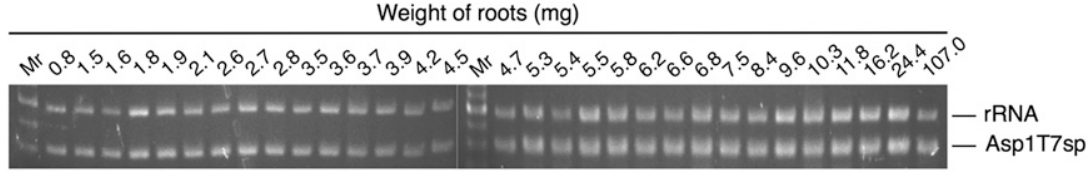

Fig. 3. Fragments amplified by polymerase chain reaction (PCR) using male-specific primers (Aspl-T7sp) and control primers [ribosomal RNA (rRNA)] with genomic DNA templates extracted from excised roots of asparagus seedlings at $19 \mathrm{~d}$ after seeding. Multiplex PCR using mixed primer sets detected the male banding pattern with genomic DNA extracted from root samples of the all-male cultivar Gijnlim. The leftmost lane represents a molecular marker $(\mathrm{Mr}) ; 1 \mathrm{mg}=3.5274 \times 10^{-5} \mathrm{oz}$.

Table 2. Sex determination of young asparagus seedlings by multiplex polymerase chain reaction (PCR). The crude DNA extract was obtained from the excised root tips of young seedlings up to day 19. Multiplex PCR was carried out with both male-specific Asp 1-T7sp primers and reaction control ribosomal RNA primers.

\begin{tabular}{|c|c|c|c|c|c|c|}
\hline \multirow[b]{2}{*}{ Cultivar } & \multirow{2}{*}{$\begin{array}{c}\text { Seedlings } \\
\text { tested } \\
\text { (no.) }\end{array}$} & \multirow{2}{*}{$\begin{array}{c}\text { Success rate of } \\
\text { determination }(\%)^{z}\end{array}$} & \multicolumn{3}{|c|}{ Seedlings determined sex (no.) } & \multirow{2}{*}{$\begin{array}{c}P \text { value } \\
\text { for } \\
\chi^{2} \text { test }^{\mathrm{v}} \\
\end{array}$} \\
\hline & & & Male $^{\mathrm{y}}$ & Female $^{\mathrm{x}}$ & $\mathrm{ND}^{\mathbf{w}}$ & \\
\hline Shower & 30 & 100 & 16 & 14 & 0 & 0.72 \\
\hline Baitoru & 26 & 96 & 15 & 10 & 1 & 0.32 \\
\hline Poletom & 27 & 100 & 15 & 12 & 0 & 0.56 \\
\hline
\end{tabular}

${ }^{z}$ (Number of seedlings whose sex could be determined $\div$ number of seedlings tested $) \times 100$.

Number of seedlings whose sex could be determined as male based on PCR amplification of both Aspl-T7sp and ribosomal RNA fragments.

${ }^{x}$ Number of seedlings whose sex could be determined as female based on PCR amplification of ribosomal RNA fragment alone.

"Number of seedlings whose sex could not be determined (PCR amplified neither fragment)

"The observed values for segregation of sex in three cultivars were analyzed by a $\chi^{2}$ test, with an expected ratio of $1: 1$

the reaction conditions used, the larger fragment might be a better marker for the PCR reaction and could significantly reduce the risk of false negatives. Furthermore, genomic DNA from an all-male cultivar serves as a useful positive control for the reaction.

In conclusion, the sex of asparagus can be determined within $19 \mathrm{~d}$ after seeding by the method established in this study. In combination with single-step DNA extraction from root tips, multiplex PCR made for a simple and reliable screening method.

\section{Literature cited}

Biffi, R., F.M. Restivo, A. Caporali, G.P. Marziani, A. Spada, and A. Falavigna. 1995. A restriction fragment length polymorphism probe for early diagnosis of gender in Asparagus officinalis L. HortScience 30:1463-1464.

Ellison, J.H. 1986. Asparagus breeding, p. 521-569. In: M.J. Bassett (ed.). Breeding vegetable crops. AVI Publishing, Westport, CT.

Falavigna, A. 1979. Pure lines of $A$. officinalis obtained by in vitro anther culture in Italy. Proc. 5th Intl. Asparagus Symp., p. 91-99.
Falavigna, A., P.E. Casali, and M.G. Taccomi. 1990. Potential of in vitro anther culture technique for asparagus. Acta Hort. 271:39-46.

Falavigna, A., P.E. Casali, and M.G. Taccomi. 1996. Advances in asparagus breeding following in vitro anther culture. Acta Hort. 415:137-142.

Fraaije, B.A., D.J. Lovell, J.M. Coelho, S. Baldwin, and D.W. Hollomon. 2001. PCR-based assays to assess wheat varietal resistance to blotch (Septoria tritici and Stagonospora nodorum) and rust (Puccinia striiformis and Puccinia recondita) diseases. Eur. J. Plant Pathol. 107:905-917.

Gebler, P., Ł. Wolko, and M. Knaflewski. 2007. Identification of molecular markers for selection of supermale (YY) asparagus plants. J. Appl. Genet. 48:129-131.

Inagaki, N., T. Harada, and T. Yakuwa. 1980. Studies on the anther culture of horticultural crops. II: Callus formation from anthers of asparagus. J. Jpn. Soc. Hort. Sci. 49:71-78.

Jamsari, A., I. Nitz, S.M. Reamon-Büttner, and C. Jung. 2004. BAC-derived diagnostic markers for sex determination in asparagus. Theor. Appl. Genet. 108:1140-1146.

Jiang, C. and K.C. Sink. 1997. RAPD and SCAR markers linked to the sex expression locus $M$ in asparagus. Euphytica 94:329333.

Maestri, E., F.M. Restivo, G.P. MarzianiLongo, A. Falavigna, and F. Tassi. 1991. Isozyme gene markers in the dioecious species Asparagus officinalis L. Theor. Appl. Genet. 81:613-618.

Moon, D. 1976. Yield potential of Asparagus officinalis L. N.Z. J. Exp. Agr. 19: 435-438.

Nakayama, H., T. Ito, Y. Hayashi, T. Sonoda, T. Fukuda, T. Ochiai, T. Kameya, and A. Kanno. 2006. Development of sex-linked primers in garden asparagus (Asparagus officinalis L.). Breeding Sci. 56:327-330.

Parasnis, A.S., V.S. Gupta, S.A. Tamhankar, and P.K. Ranjekar. 2000. A highly reliable sex diagnostic PCR assay for mass screening of papaya seedlings. Mol. Breeding 6: 337-344.

Pastrik, K-H. 2000. Detection of Clavibacter michiganensis subsp. sepedonicus in potato tubers by multiplex PCR with coamplification of host DNA. Eur. J. Plant Pathol. 106:155-165.

Reamon-Büttner, S.M. and C. Jung. 2000. AFLP-derived STS markers for the identification of sex in Asparagus officinalis L. Theor. Appl. Genet. 100: $432-438$

Reamon-Büttner, S.M., J. Schondelmaier, and C. Jung. 1998. AFLP markers tightly linked to the sex locus in Asparagus officinalis L. Mol. Breeding 4:9198

Shiga, I., Y. Uno, M. Kanechi, and N. Inagaki. 2009. Identification of polyploidy of in vitro anther-derived shoots of Asparagus officinalis L. by flow cytometric analysis and measurement of stomatal length. J. Jpn. Soc. Hort. Sci. 78: 103-108.

Shiobara, Y., M. Yoshino, A. Uragami, A. Widiastuti, A. Omori, K. Kuba, H. Saito, Y. Hirata, T. Sonoda, T. Koizumi, and T. Sato. 2011. Sex distinction of asparagus by loop-mediated isothermal amplification and observation of seedling phenotypes. Euphytica 177:91-97.

Sinton, S. and D.R. Wilson. 1999. Comparative performance of male and female plants during the annual growth cycle of a dioecious asparagus cultivar. Acta Hort. 479:347-353.

Sneep, J. 1953. The significance of andromonoecy for the breeding of Asparagus officinalis L. Euphytica 2:89-95.

Thomson, D. and R. Henry. 1995. Singlestep protocol for preparation of plant tissue for analysis by PCR. Biotechniques 19: $394-400$ 


\section{Research Reports}

Torrey, D. and L. Peirce. 1983. Production of haploid plantlets from anthers of asparagus. HortScience 18:569 (abstr.).

Uesugi, T., M. Shiokawa, and H. Baba. 1992. Characteristics of seed derived plants and in vitro propagated clones in Asparagus officinalis L. (in Japanese with English summary). Bul. Nagano Veg. Ornamental Crops Expt. Sta. 7:11-16.

Uragami, A. 1988. In vitro propagation of asparagus and its utilization in breeding. (in Japanese) Agr. Hort. 63:271-273.
Uragami, A., K. Ito, M. Nagai, H. Yoshikawa, Y. Satoh, S. Komochi, T. Muro, and M. Morishita. 2011. New all-male asparagus hybrid 'Zuiyu'. (in Japanese with English summary). Res. Bul. Natl. Agr. Res. Ctr. Hokkaido Reg. 193:1-10.

Urasaki, N., K. Tarora, T. Uehara, I. Chinen, R. Terauchi, and M. Tokumoto. 2002. Rapid and highly reliable sex diagnostic PCR assay for papaya (Carica papaya L.). Breeding Sci. 52:333-335.
Walker, S., L.K. Inaba, S.A. Garrison, C. Chin, and W. Odermott. 1999. Commercial production of high quality hybrid asparagus seed with high genetic purity. Acta Hort. 479:407-414.

Winton, M.W. and E.M. Hansen. 2001. Molecular diagnosis of Phytophthora latevalis in trees, water, and foliage baits using multiplex polymerase chain reaction. For. Pathol. 31:275-283. 